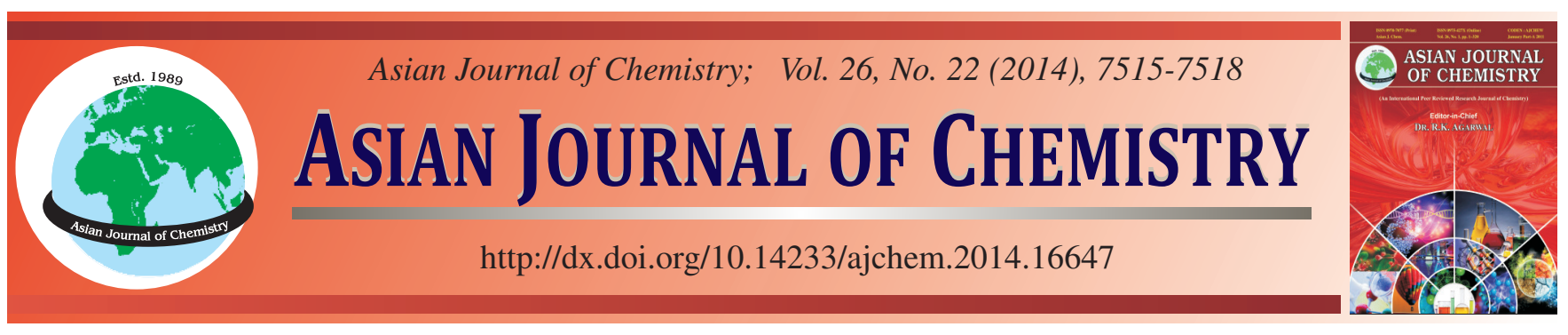

\title{
Synthesis and Spectroscopic Characterization of Some Novel Schiff Base Complexes of Transition Metals and Their Biological Studies
}

\author{
Netra Pal Singh", PoOnam Saini and Asvini Kumar
}

Department of Chemistry, Meerut College, Meerut-250 001, India

*Corresponding author: E-mail: npsmcm.in@gmail.com

Cobalt(II) and manganese(II) complexes of novel Schiff base derived from 4,5-dimethoxy-1,2-phenylenediamine and 5-substituted salicylaldehyde have been synthesized and characterized by various physico-chemical techniques viz. elemental analysis, magnetic moment, IR, NMR and electronic spectral studies. The complexes have been found to have a stoichiometry of 1:1 (M:L). The probable geometry and biological activity of the complexes also have been reported.

Keywords: Novel Schiff base, Co(II), Mn(II) Complexes, Biological activity.

\section{INTRODUCTION}

The condensation of primary amine with carbonyl compounds yields Schiff base ${ }^{1-3}$. The resultant imines $\left(\mathrm{R}_{1} \mathrm{HC}=\mathrm{N}-\right.$ $\mathrm{R}_{2}$ ) participate in binding with metal ions via nitrogen lone pair electrons. In the recent years, there has been considerable interest in the chemistry of transition metal complexes of Schiff base $^{4-6}$. This is due to the fact that Schiff base offer opportunities for substrate chirality, tuning the metal centred electronic factor enhancing the solubility and stability of either homogeneous or heterogeneous catalysts ${ }^{7-12}$. Schiff base-transition metal complexes are one of the most adaptable and throughly studied systems $^{13-14}$. These complexes have also applications in clinical $^{15}$ and analytical fields ${ }^{16}$. Some of Schiff base complexes are used as model molecules for biological oxygen carrier systems ${ }^{17}$. A large number of Schiff base complexes ${ }^{18-21}$ have been tested for antimicrobial activities and they have been found antibacterial, antifungal ${ }^{22-26}$, anticancer ${ }^{27,28}$ and herbicidal ${ }^{29}$. Tetradentate Schiff base complexes are well known to form stable complexes, where the coordination takes place through the $\mathrm{N}_{2} \mathrm{O}_{2}$ donor set ${ }^{30-32}$.

In the present paper, we report the synthesis, spectroscopic characterization and biological activities of $\mathrm{Co}$ (II) and $\mathrm{Mn}$ (II) complexes with Schiff-base derived from 4,5-dimethoxy-1,2phenylenediamine and 5-substituted salicylaldehyde.

\section{EXPERIMENTAL}

All the chemicals and solvents used were of AR grade. 4,5Dimethoxy-1,2-phenylenediamine and 5-substituted salicylaldehyde were obtained from Central Drug House, New Delhi.
Synthesis of ligands: The Schiff base ligand was prepared by mixing of ethanolic solution of 4,5-dimethoxy-1,2-phenylenediamine $(1 \mathrm{~mol})$ with an ethanolic solution of respective salicylaldehyde (2 mol) in a 1:2 stoichiometric ratio. The resulting solution then refluxed with stirring for $2 \mathrm{~h}$. The precipitate was collected by filtration, recrystallized from ethanol and dried at room temperature (Scheme-I).<smiles>COc1cc(C=Nc2cc(OC)c(OC)cc2N=Cc2cc(C)ccc2O)c(OC)cc1N</smiles>

Scheme-I: Synthesis of ligand (where $\mathrm{X}=\mathrm{F}^{-}, \mathrm{Cl}^{-}, \mathrm{Br}^{-}$)

Synthesis of metal complexes: A general method has been adopted for the isolation of complexes in solid state. Hot ethanolic solution of metal salts $\left(\mathrm{CoCl}_{2} \cdot 6 \mathrm{H}_{2} \mathrm{O}\right.$ and $\left.\mathrm{MnCl}_{2} \cdot 4 \mathrm{H}_{2} \mathrm{O}\right)$ and solution of respective ligand were mixed in 1:1 molar ratio. The resulting solution was refluxed with stirring for $4 \mathrm{~h}$ and then kept overnight to insure the complete reaction. Thus, the formed complexes were filtered, collected and then washed with hot ethanol until the filtrate becomes colourless. The complexes were dried in a desiccators (Fig. 1). 


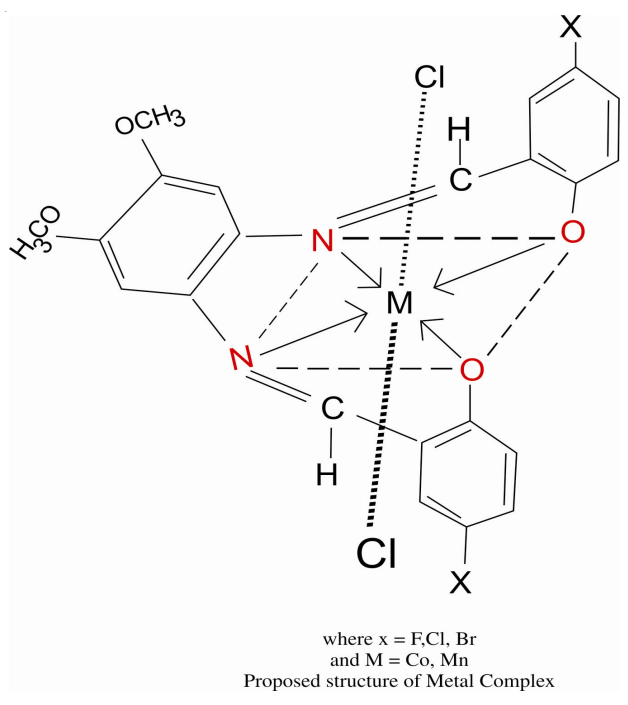

Fig. 1. Proposed structure of metal complex

Elemental analysis was performed on Elemental Vario ELIII automatic equipment. The IR spectra were recorded on Thermo-Nicolet Nixus FTIR automatic recording spectrophotometer. Shimadzu UV and visible spectrophotometer $1601 \mathrm{CP}$ provided with an automatic recorder was used to record the electronic spectra. The magnetic susceptibility of all the metal complexes was determined using Gauys method, suspending the specimen tube filled with the powdered complex. Murcury(II) tetrathiocynate cobaltate(II) $\mathrm{HgCo}(\mathrm{CNS})_{4}$ was used as calibrant.

\section{RESULTS AND DISCUSSION}

The compositional data of the synthesized compounds are in good agreement with their suggested stoichiometries (Table-1). All the metal complexes are soluble in common organic solvents such as DMF and DMSO.

\begin{tabular}{|c|c|c|c|c|c|c|c|}
\hline \multirow{3}{*}{$\begin{array}{c}\text { S. } \\
\text { No. }\end{array}$} & \multicolumn{7}{|c|}{$\begin{array}{l}\text { TABLE } 1 \\
\text { ANALYTICAL DATA OF SCHIFF BASE } \\
\text { AND METAL COMPLEXES }\end{array}$} \\
\hline & \multirow[t]{2}{*}{ Mol. Formula } & \multirow{2}{*}{ m.w. } & \multirow{2}{*}{$\begin{array}{l}\text { Yield } \\
(\%)\end{array}$} & \multicolumn{4}{|c|}{$\begin{array}{l}\text { Elemental calculated } \\
\text { (Observed) }\end{array}$} \\
\hline & & & & $\mathrm{C}$ & $\mathrm{H}$ & $\mathrm{N}$ & M \\
\hline 1 & $\mathrm{C}_{22} \mathrm{H}_{18} \mathrm{~N}_{2} \mathrm{O}_{4} \mathrm{Cl}_{2}\left(\mathrm{~L}_{1}\right)$ & 445 & 76 & $\begin{array}{c}59.32 \\
(59.21)\end{array}$ & $\begin{array}{c}4.04 \\
(4.06)\end{array}$ & $\begin{array}{c}6.30 \\
(6.42)\end{array}$ & $\begin{array}{l}- \\
-\end{array}$ \\
\hline 2 & $\mathrm{C}_{22} \mathrm{H}_{16} \mathrm{~N}_{2} \mathrm{O}_{4} \mathrm{Cl}_{4} \mathrm{Co}\left(\mathrm{CoL}_{1}\right)$ & 573 & 82 & $\begin{array}{c}46.07 \\
(46.12)\end{array}$ & $\begin{array}{c}2.80 \\
(2.82)\end{array}$ & $\begin{array}{c}4.89 \\
(4.87)\end{array}$ & $\begin{array}{r}10.30 \\
(10.28)\end{array}$ \\
\hline 3 & $\mathrm{C}_{22} \mathrm{H}_{16} \mathrm{~N}_{2} \mathrm{O}_{4} \mathrm{Cl}_{4} \mathrm{Mn}\left(\mathrm{MnL}_{1}\right)$ & 569 & 87 & $\begin{array}{c}46.40 \\
(46.32)\end{array}$ & $\begin{array}{c}2.81 \\
(2.72)\end{array}$ & $\begin{array}{c}4.92 \\
(4.91)\end{array}$ & $\begin{array}{c}9.67 \\
(9.61)\end{array}$ \\
\hline 4 & $\mathrm{C}_{22} \mathrm{H}_{18} \mathrm{~N}_{2} \mathrm{O}_{4} \mathrm{Br}_{2}\left(\mathrm{~L}_{2}\right)$ & 534 & 71 & $\begin{array}{c}49.44 \\
(49.50)\end{array}$ & $\begin{array}{c}3.37 \\
(3.32)\end{array}$ & $\begin{array}{c}5.24 \\
(5.21)\end{array}$ & $\begin{array}{l}- \\
-\end{array}$ \\
\hline 5 & $\begin{array}{l}\mathrm{C}_{22} \mathrm{H}_{16} \mathrm{~N}_{2} \mathrm{O}_{4} \mathrm{Br} \\
{ }_{2} \mathrm{Cl}_{2} \mathrm{Co}\left(\mathrm{CoL}_{2}\right)\end{array}$ & 662 & 79 & $\begin{array}{c}39.88 \\
(39.80)\end{array}$ & $\begin{array}{c}2.42 \\
(2.49)\end{array}$ & $\begin{array}{c}4.23 \\
(4.28)\end{array}$ & $\begin{array}{c}8.91 \\
(8.87)\end{array}$ \\
\hline 6 & $\begin{array}{l}\mathrm{C}_{22} \mathrm{H}_{16} \mathrm{~N}_{2} \mathrm{O}_{4} \mathrm{Br}_{2} \mathrm{Cl}_{2} \\
\mathrm{Mn}\left(\mathrm{MnL}_{2}\right)\end{array}$ & 658 & 83 & $\begin{array}{c}40.12 \\
(40.08)\end{array}$ & $\begin{array}{c}2.43 \\
(2.40)\end{array}$ & $\begin{array}{c}4.35 \\
(4.21)\end{array}$ & $\begin{array}{c}8.36 \\
(8.40)\end{array}$ \\
\hline 7 & $\mathrm{C}_{22} \mathrm{H}_{18} \mathrm{~N}_{2} \mathrm{O}_{4} \mathrm{~F}_{2}\left(\mathrm{~L}_{3}\right)$ & 412 & 68 & $\begin{array}{l}64.08 \\
(64.11)\end{array}$ & $\begin{array}{c}4.37 \\
(4.37)\end{array}$ & $\begin{array}{c}6.80 \\
(6.72)\end{array}$ & $\begin{array}{l}- \\
-\end{array}$ \\
\hline 8 & $\begin{array}{l}\mathrm{C}_{22} \mathrm{H}_{16} \mathrm{~N}_{2} \mathrm{O}_{4} \mathrm{~F}_{2} \mathrm{Cl} \\
{ }_{2} \mathrm{CO}\left(\mathrm{CoL}_{3}\right)\end{array}$ & 540 & 84 & $\begin{array}{c}48.89 \\
(48.81)\end{array}$ & $\begin{array}{c}2.36 \\
(2.96)\end{array}$ & $\begin{array}{c}5.18 \\
(5.21)\end{array}$ & $\begin{array}{c}10.92 \\
(10.93)\end{array}$ \\
\hline 9 & $\begin{array}{l}\mathrm{C}_{22} \mathrm{H}_{16} \mathrm{~N}_{2} \mathrm{O}_{4} \mathrm{~F}_{2} \mathrm{Cl}_{2} \\
\mathrm{Mn}\left(\mathrm{MnL}_{3}\right)\end{array}$ & 536 & 77 & $\begin{array}{l}49.25 \\
(49.26)\end{array}$ & $\begin{array}{c}2.98 \\
(2.91)\end{array}$ & $\begin{array}{c}5.22 \\
(5.18)\end{array}$ & $\begin{array}{c}10.21 \\
(10.26)\end{array}$ \\
\hline
\end{tabular}

Infrared spectra: The IR data of the Schiff base and its complexes are listed in Table-2. Comparison of the IR spectra

\begin{tabular}{ccccccccc}
\hline \multicolumn{1}{c}{ TABLE-2 } \\
\multicolumn{8}{c}{$\begin{array}{c}\text { SELECTED IR FREQUENCIES OF SCHIFF BASE } \\
\text { AND ITS METAL COMPLEXES }\left(\mathrm{cm}^{-1}\right)\end{array}$} \\
$\begin{array}{cccccccccc}\mathrm{S} . \\
\text { No. }\end{array}$ & $\mathrm{Com}$. & $v(-\mathrm{H})$ & $v(-\mathrm{OH})$ & $v(\mathrm{C}-\mathrm{O})$ & $v(\mathrm{C}-\mathrm{N})$ & $v(\mathrm{M}-\mathrm{N})$ & $v(\mathrm{M}-\mathrm{O})$ & $v(\mathrm{M}-\mathrm{Co})$ \\
\hline 1 & $\mathrm{~L}_{1}$ & 3055 & 3332 & 1366 & 1622 & - & - & - \\
2 & $\mathrm{Co}-\mathrm{L}_{1}$ & 3042 & 3342 & 1350 & 1596 & 432 & 532 & 312 \\
3 & $\mathrm{Mn}-\mathrm{L}_{1}$ & 3062 & 3340 & 1341 & 1604 & 448 & 517 & 317 \\
4 & $\mathrm{~L}_{2}$ & 3221 & 3326 & 1380 & 1612 & - & - & - \\
5 & $\mathrm{Co}-\mathrm{L}_{2}$ & 3228 & 3346 & 1367 & 1591 & 420 & 541 & 305 \\
6 & $\mathrm{Mn}-\mathrm{L}_{2}$ & 3232 & 3348 & 1365 & 1597 & 438 & 546 & 308 \\
7 & $\mathrm{~L}_{3}$ & 3140 & 3338 & 1375 & 1680 & - & - & - \\
8 & $\mathrm{Co}-\mathrm{L}_{3}$ & 3148 & 3355 & 1365 & 1668 & 463 & 522 & 306 \\
9 & $\mathrm{Mn}-\mathrm{L}_{3}$ & 3170 & 3351 & 1352 & 1655 & 450 & 537 & 314 \\
\hline
\end{tabular}

of Schiff base ligands with that of its complexes show the absorption bands in the range 1630-1612 $\mathrm{cm}^{-1}$ and 1380-1366 $\mathrm{cm}^{-1}$ due to azomethine $\mathrm{v}(\mathrm{C}=\mathrm{N})$ and phenolic $\mathrm{v}(\mathrm{C}=\mathrm{O})$ groups respectively. The $(\mathrm{C}=\mathrm{N})$ vibrations decreased by $12-26 \mathrm{~cm}^{-1}$, on complexation showing involvement of nitrogen of azomethine group in coordination ${ }^{33}$. This is further substantiated by the presence of a new band around $463-420 \mathrm{~cm}^{-1}$ assignable to $v(\mathrm{M}-\mathrm{N})^{34}$. The absence of stretching and bending vibrations of free carbonyl group at about $1700 \mathrm{~cm}^{-1}$ indicates the absence of this group in these complexes ${ }^{35}$. The (C-O) vibrations decreased by $10-25 \mathrm{~cm}^{-1}$ relative to the free ligands suggesting involvement of the oxygen atom of the C-O moiety in coordination ${ }^{36}$. Presence of new bands in the region 546$517 \mathrm{~cm}^{-1}$ due to $v(\mathrm{M}-\mathrm{O})$ also support the coordination of ligand through phenolic oxygen with metal ${ }^{37}$.

Thus, it can be concluded that the Schiff base is a tetradentate ligand coordinating via the azomethine $\mathrm{N}$ and the phenolic $\mathrm{O}$. The infrared spectra show bands in the region $317-305 \mathrm{~cm}^{-1}$ corresponding to $(\mathrm{M}-\mathrm{Cl})$ vibrations ${ }^{38}$.

Electronic spectra: The electronic spectra of the ligand and complexes are summarised in Table-5. These data also support the structural formulae of the ligand and complexes. The band observed in the range $252-270 \mathrm{~nm}$ is attributed to benzene $\pi \rightarrow \pi^{*}$ transitions. The band in the range 326-338 $\mathrm{nm}$ assignable to $\pi \rightarrow \pi^{*}$ transitions of non-bonding electrons present in the nitrogen of the azomethine group on the ligand. After complexation this azomethine group of ligand changes to azomethine linkage in all the cobalt and manganese complexes which is confirmed through the presence of intense band around 345-352 and 342-356 nm, respectively and assignable to $\pi \rightarrow \pi^{*}$.

\begin{tabular}{|c|c|c|c|c|c|c|}
\hline \multicolumn{7}{|c|}{$\begin{array}{c}\text { TABLE-3 } \\
\text { ANTIMICROBIAL EFFECTS OF THE LIGANDS } \\
\text { AND THEIR METAL COMPLEXES }\end{array}$} \\
\hline \multirow{2}{*}{$\begin{array}{c}\text { S. } \\
\text { No. }\end{array}$} & \multirow{2}{*}{ Com. } & \multicolumn{5}{|c|}{ Inhibition zone $(\mathrm{mm})$} \\
\hline & & E. Coli & S. epidermidits & A. flavus & A. Niger & C. Lunata \\
\hline 1 & $\mathrm{~L}_{1}$ & 7 & 6 & 9 & 11 & 10 \\
\hline 2 & $\mathrm{Co}-\mathrm{L}_{1}$ & 13 & 15 & 15 & 12 & 11 \\
\hline 3 & $\mathrm{Mn}-\mathrm{L}_{1}$ & 12 & 16 & 14 & 15 & 18 \\
\hline 4 & $\mathrm{~L}_{2}$ & 9 & 8 & 13 & 10 & 11 \\
\hline 5 & $\mathrm{Co}-\mathrm{L}_{2}$ & 15 & 16 & 14 & 16 & 12 \\
\hline 6 & $\mathrm{Mn}-\mathrm{L}_{2}$ & 14 & 15 & 17 & 13 & 14 \\
\hline 7 & $\mathrm{~L}_{3}$ & 8 & 7 & 12 & 12 & 10 \\
\hline 8 & $\mathrm{Co}-\mathrm{L}_{3}$ & 12 & 14 & 16 & 17 & 17 \\
\hline 9 & $\mathrm{Mn}-\mathrm{L}_{3}$ & 13 & 11 & 15 & 14 & 16 \\
\hline
\end{tabular}


Cobalt(II) complexes showed absorption band in the range 467-481 and 312-348 $\mathrm{nm}$. The bands can be assigned to ${ }^{4} \mathrm{~T}_{1 \mathrm{~g}}(\mathrm{~F})$ $\rightarrow{ }^{4} \mathrm{~A}_{2 \mathrm{~g}}$ and ${ }^{4} \mathrm{~T}_{1 \mathrm{~g}}(\mathrm{~F}) \rightarrow 4 \mathrm{~T}_{1 \mathrm{~g}}(\mathrm{P})$ transitions, respectively which are in accordance with $\mathrm{Co}(\mathrm{II})$ high spin octahedral geometry ${ }^{39}$. Further the magnetic moment of $\mathrm{Co}(\mathrm{II})$ complexes (4.58-4.89) BM suggest a high spin octahedral geometry ${ }^{40}$ (Table-4).

\section{TABLE-4}

MAGNETIC MOMENT OF METAL COMPLEXES

\begin{tabular}{ccc}
\hline S. No. & Complex & Magnetic moment (BM) \\
\hline 1 & Co- $\mathrm{L}_{1}$ & 4.67 \\
2 & Mn- $\mathrm{L}_{1}$ & 5.83 \\
3 & Co-L $_{2}$ & 4.58 \\
4 & Mn-L $_{2}$ & 5.94 \\
5 & Co- $\mathrm{L}_{3}$ & 4.89 \\
6 & $\mathrm{Mn}-\mathrm{L}_{3}$ & 5.97 \\
\hline
\end{tabular}

Manganese(II) complexes showed bands in the range 618$625,490-503,478-484,375-390 \mathrm{~nm}$ which are assigned to ${ }^{6} \mathrm{~A}_{1 \mathrm{~g}} \rightarrow{ }^{6} \mathrm{~T}_{1 \mathrm{~g}},{ }^{6} \mathrm{~A}_{1 \mathrm{~g}} \rightarrow{ }^{4} \mathrm{~T}_{2 \mathrm{~g}},{ }^{6} \mathrm{~A}_{1 \mathrm{~g}} \rightarrow{ }^{4} \mathrm{E}_{\mathrm{g}}$ and ${ }^{6} \mathrm{~A}_{1 \mathrm{~g}} \rightarrow{ }^{4} \mathrm{~T}_{1 \mathrm{~g}}$, respectively, a characteristic of octahedral geometry ${ }^{41}$. The magnetic moment of $\mathrm{Mn}$ (II) complexes lie in the range 5.83-5.97 BM, which is indicative of octahedral geometry ${ }^{42}$.

${ }^{1} \mathrm{H}$ NMR and ${ }^{13} \mathrm{C}$ NMR spectra: Further evidence for the coordination of the ligand to the metal ion $\mathrm{Co}$ (II) and $\mathrm{Mn}$ (II) is provided by the ${ }^{1} \mathrm{H}$ NMR and ${ }^{13} \mathrm{C}$ NMR. All these spectra are given in the Table-5. The ${ }^{1} \mathrm{H}$ NMR spectra of the Schiff base exhibits a singlet signal in the region $\delta$ 8.89-8.98 and multiplet in the region $\delta 6.82-7.72$ attributed to azomethine protons ${ }^{43}$ and aromatic protons ${ }^{44}$, respectively. The ${ }^{1} \mathrm{H}$ NMR spectra of Schiff base ligand showed slight signal in the region $\delta$ 12.94-13.81 attributed to two phenolic -OH protons. In addition, the signals of azomethine protons of metal complexes shifted to downfield region $\delta 9.07-\delta 9.31$ in comparison with that of the free ligands. This confirm the involvement of $\mathrm{N}$-atom with metal ions ${ }^{45}$. The ${ }^{1} \mathrm{H}$ NMR spectra of Schiff base also exhibits a multiplet at $\delta 3.72-3.85$ attributed to $-\mathrm{OCH}_{3}$ protons, it was observed in the metal complexes.

\begin{tabular}{|c|c|c|c|c|c|c|c|c|}
\hline \multirow{3}{*}{$\begin{array}{l}\text { S. } \\
\text { No. }\end{array}$} & \multicolumn{8}{|c|}{$\begin{array}{c}\text { TABLE-5 } \\
\text { ELECTRONIC SPECTRAL AND NMR DATA OF } \\
\text { SCHIFF BASE LIGAND AND ITS COMPLEXES }\end{array}$} \\
\hline & \multirow{2}{*}{ Comp. } & \multirow{2}{*}{$\begin{array}{l}\lambda_{\max } \\
(\mathrm{nm})\end{array}$} & \multicolumn{4}{|c|}{${ }^{1} \mathrm{H}$ NMR data (at ppm) } & \multicolumn{2}{|c|}{$\begin{array}{c}{ }^{13} \mathrm{C} \text { NMR data } \\
\text { (at } 10 \mathrm{ppm} \text { ) }\end{array}$} \\
\hline & & & $-\mathrm{OH}$ & $\mathrm{Ar}$ & $\mathrm{HC}=\mathrm{N}$ & $-\mathrm{OCH}_{3}$ & HC.N & $-\mathrm{OCH}_{3}$ \\
\hline 1 & $L_{1}$ & 252,335 & 13.81 & $6.82-7.56$ & 8.89 & 3.76 & 164.2 & 57.2 \\
\hline 2 & Co- $\mathrm{L}_{1}$ & 477,312 & & $6.76-6.93$ & 9.06 & 3.77 & 164.3 & 57.4 \\
\hline 3 & $\mathrm{Mn}-\mathrm{L}_{1}$ & 625,493 & & $6.51-7.22$ & 9.07 & 3.81 & 165.5 & 57.5 \\
\hline 4 & $\mathrm{~L}_{2}$ & 270,326 & 13.23 & $6.94-7.62$ & 8.98 & 3.72 & 168.9 & 55.2 \\
\hline 5 & $\mathrm{Co}-\mathrm{L}_{2}$ & 467,348 & & $6.68-7.41$ & 9.06 & 3.76 & 170.1 & 55.8 \\
\hline 6 & $\mathrm{Mn}-\mathrm{L}_{2}$ & 621,490 & & $6.75-7.11$ & 9.13 & 3.78 & 171.4 & 56.2 \\
\hline 7 & $\mathrm{~L}_{3}$ & 268,338 & 12.94 & $7.10-7.72$ & 8.97 & 3.85 & 162.6 & 55.8 \\
\hline 8 & $\mathrm{Co}-\mathrm{L}_{3}$ & 481,337 & & $6.83-7.34$ & 9.18 & 3.86 & 168.3 & 56.9 \\
\hline 9 & $\mathrm{Mn}-\mathrm{L}_{3}$ & 503,618 & & $6.92-7.40$ & 9.12 & 3.81 & 170.2 & 57.2 \\
\hline
\end{tabular}

In ${ }^{13} \mathrm{C}$ NMR spectra, the signals at $\delta 55.2-58.7$ is attributed to $-\mathrm{OCH}_{3}$ carbon ${ }^{46}$ and the signals at $\delta 162.6-173.4$ is attributed to azomethine carbon.

Anitimicrobial studies: The antimicrobial activities of ligands and its complexes were tested in vitro against S. epidermidis, E. coli, A. flavus, A. niger and C. lunata by reported method ${ }^{47}$. On comparing the antimicrobial activities of Schiff base ligand and its metal complexes, we found that the complexes exhibit more activity then that of the ligands. The increase in the activity of the complexes compared to that of the ligands could be explained on the basis of Overtone's concept $^{48}$ and Tweedy's chelation theory ${ }^{49}$.

\section{Conclusion}

On the basis of above mentioned studies, we have proposed the octahedral geometry for the metal complexes and the antimicrobial results showed that these metal complexes are more potent then that of Schiff base ligands.

\section{REFERENCES}

1. K.S. Murray, A.M. van den Bergen and B.O. West, Aust. J. Chem., 31, 203 (1978).

2. K. Dey, A.K. Biswas and A. Roy, Indian J. Chem., 20A, 848 (1981).

3. Z. Guan, P.M. Cotts, E.F. McCord and S.J. McLain, Science, 283, 2059 (1999).

4. K.S. Murray, B.A.M. Van and B.O. West, Aust. J. Chem., 31, 203 (1978).

5. H. Doine, F.F. Stephens and R.D. Cannon, Bull. Chem. Soc. Jpn., 58, 1327 (1985).

6. K. Nakajima, Y. Ando, H. Mano and M. Kojima, Inorg. Chim. Acta, 274, 184 (1998).

7. B. De Clercq and F. Verpoort, Macromolecules, 35, 8943 (2002).

8. T. Opstal and F. Verpoort, Angew. Chem. Int. Ed., 42, 2876 (2003).

9. T. Opstal and F. Verpoort, Synlett., 935 (2002).

10. S.N. Pal and S. Pal, Inorg. Chem., 40, 4807 (2001).

11. B. De Clercq and F. Verpoort, Adv. Synth. Catal., 344, 639 (2002).

12. B.D. Clercq, F. Lefebvre and F. Verpoor, Appl. Catal. A, 247, 345 (2003).

13. I.M.I. Falhr, N.A. Hamdy, M.A. Radwan and Y.M. Ahmed, Egypt. J. Chem., 201 (2004).

14. (a) P.S. Dixit and K. Srinivasan, Inorg. Chem., 27, 4507 (1988); (b) A. Nishinaga, T. Tojo and T. Matsuura, J. Chem. Soc. Chem. Commun., 896 (1974)

15. A. Mohindru, J.M. Fisher and M. Rabinovitz, Nature, 303, 64 (1983).

16. P.R. Palet and B.T. Thaker, Indian J. Chem., A38, 563 (1999).

17. R.E. Hester and E.M. Nour, J. Raman Spectrosc., 11, 39 (1981).

18. K. Drabent, A. Bialonska and Z. Ciunik, Inorg. Chem. Commun., 7, 224 (2004).

19. M.H. Klingele and S. Brooker, Coord. Chem. Rev., 241, 119 (2003).

20. V.B. Arion, E. Reisner, M. Fremuth, M.A. Jakupec, B.K. Keppler, V.Y. Kukushkin and A.J.L. Pombeiro, Inorg. Chem., 42, 6024 (2003).

21. M. Mashaly, H.A. Boyoumi and A. Taha, Chem. Papers, 53, 299 (1999).

22. A.S. Kabeer, M.A. Baseer and N.A. Mote, Asian J. Chem., 13, 496 (2001).

23. A.H. El-masry, H.H. Fahmy and S.H. Ali Abdelwahed, Molecules, 5, 1429 (2000).

24. P.G. More, R.B. Bhalvankar and S.C. Patter, J. Indian Chem. Soc., 78, 474 (2001).

25. S.N. Pandeya, D. Sriram, G. Nath and E. De Clercq, Il Farmaco, 54, 624 (1999).

26. W.M. Singh and W.C. Dash, Pesticides, 22, 33 (1998).

27. S.B. Desai, P.B. Desai and K.R. Desai, Heterocycl. Commun., 7, 83 (2001).

28. P. Pathak, V.S. Jolly and K.P. Sharma, Orient. J. Chem., 16, 161 (2000).

29. S. Samadhiya and A. Holve, Orient. J. Chem., 17, 119 (2001).

30. E.M. Nour, A.A. Taha and I.S. Alnaimi, Inorg. Chim. Acta, 141, 139 (1988).

31. E.M. Nour, A.M. Al-Kority, S.A. Sadeek and S.M. Teleb, Synth. React. Inorg. Met-org. Chem., 23, 39 (1993).

32. W. Wang, F.L. Zeng, X. Wang and M.-Y. Tan, Polyhedron, 15, 1699 (1996).

33. P.E. Aranha, J.M. Souza, S. Romera, L.A. Ramos, M.P. dos Santos, E.R. Dockal and E.T.G. Cavalheiro, Thermochim. Acta, 453, 9 (2007).

34. T.M. Bhagat, D.K. Swamy and M.N. Deshpande, J. Chem. Pharm Res., 4, 100 (2012).

35. D.A. House and N.F. Curtis, J. Am. Chem. Soc., 86, 1331 (1964). 
36. M. Tümer, C. Çelik, H. Köksal and S. Serin, Transition Met. Chem., 24, 525 (1999)

37. X. Tai, X. Yin, Q. Chen and M. Tan, Molecules, 8, 439 (2003).

38. P.T.T. Wong and D.G. Brewer, Can. J. Chem., 46, 131 (1968).

39. B.N. Figgis and J. Lewis, Prog. Inorg. Chem., 6, 37 (1964).

40. B. Anupama and C.G. Kumari, Int. J. Res. Chem. Environ, 3, 172 (2013).

41. A.B.P. Lever, Inorganic Electronic Spectroscopy Elsevier, Amsterdem (1968)

42. B.K. Sahu and B.K. Mahapatra, J. Indian Chem. Soc., 56, 825 (1979).

43. M. Odabasoglu, F. Arslan, H. Olmez and O. Büyükgüngör, Dyes Pigments, 75, 505 (2007)
44. H. Naeimi, J. Safari and A. Heidarnezhad, Dyes Pigments, 73, 251 (2007).

45. K. Singh, M.S. Barwa and P. Tyagi, Eur. J. Med. Chem., 41, 147 (2006)

46. K.-H. Chang, C.-C. Huang, Y.-H. Liu, Y.-H. Hu, P.-T. Chou and Y.-C. Lin, Dalton Trans., 1731 (2004).

47. J. Parekh, P. Inamdhar, R. Nair, S. Baluja and S. Chanda, J. Serb. Chem. Soc., 70, 1155 (2005).

48. C.E. Overton, Studien Uber die Norkose Zugleichein Beitrag Zur allgemeinon Pharmokologi, Gustav Fisher, Jena, Switzerland (1901).

49. B.G. Tweedy, Phytopathology, 55, 910 (1901). 